\title{
Precipitous decline of white-lipped peccary populations in Mesoamerica
}

Daniel Thornton $^{\mathrm{a}, *}$, Rafael Reyna ${ }^{\mathrm{b}}$, Lucy Perera-Romero ${ }^{\mathrm{a}}$, Jeremy Radachowsky ${ }^{\mathrm{c}}$, Mircea G. Hidalgo-Mihart ${ }^{\mathrm{d}}$, Rony Garcia ${ }^{\mathrm{c}}$, Roan McNab ${ }^{\mathrm{c}}$, Lee Mcloughlin ${ }^{\mathrm{c}}$, Rebecca Foster ${ }^{\mathrm{e}}$, Bart Harmsen $^{\mathrm{e}, \mathrm{f}}$, José F. Moreira-Ramírez ${ }^{\mathrm{c}}$, Fabricio Diaz-Santos ${ }^{\mathrm{c}}$, Christopher Jordan ${ }^{\mathrm{e}, \mathrm{g}}$, Roberto Salom-Pérez ${ }^{\mathrm{e}}$, Ninon Meyer ${ }^{\mathrm{b}, \mathrm{h}}$, Franklin Castañeda ${ }^{\mathrm{e}}$, Fausto Antonio Elvir Valle $\mathrm{e}^{\mathrm{i}}$, Gabriela Ponce Santizo ${ }^{c}$, Ronit Amit ${ }^{\mathrm{j}, \mathrm{k}}$, Stephanny Arroyo-Arce ${ }^{1}$, Ian Thomson, Ricardo Moreno $^{\mathrm{h}, \mathrm{m}}$, Cody Schank ${ }^{\mathrm{g}, \mathrm{n}}$, Paulina Arroyo-Gerala ${ }^{\mathrm{o}}$, Horacio V. Bárcenas ${ }^{\mathrm{p}}$, Esteben Brenes-Mora ${ }^{g, q}$, Ana Patricia Calderón ${ }^{\mathrm{e}}$, Michael V. Cove ${ }^{\mathrm{r}}$, Diego Gomez-Hoyos ${ }^{\mathrm{s}}$, José González-Maya ${ }^{s}$, Danny Guy ${ }^{1}$, Gerobuam Hernández Jiménez ${ }^{\mathrm{t}}$, Maarten Hofman ${ }^{\mathrm{u}}$, Roland Kays $^{\mathrm{m}, \mathrm{v}}$, Travis King ${ }^{\mathrm{a}}$, Marcio Arnoldo Martinez Menjivar ${ }^{\mathrm{w}}$, Javier de la Maza ${ }^{\circ}$, Rodrigo León-Pérez ${ }^{\circ}$, Victor Hugo Ramos ${ }^{\mathrm{b}}$, Marina Rivero ${ }^{\mathrm{x}}$, Sergio Romo-Asunción ${ }^{\mathrm{x}}$, Rugieri Juárez-López ${ }^{\mathrm{d}}$, Alejandro Jesús-de la Cruz ${ }^{\mathrm{d}, \mathrm{e}}$, J. Antonio de la Torre ${ }^{\mathrm{x}}$, Valeria Towns ${ }^{\circ}$, Jan Schipper ${ }^{\mathrm{y}}$, Hector Orlando Portillo Reyes ${ }^{\mathrm{i}}$, Adolfo Artavia ${ }^{\mathrm{h}}$, Edwin Hernández-Perez ${ }^{\mathrm{z}}$, Wilber Martínez $^{\mathrm{b}}$, Gerald R. Urquhart ${ }^{\mathrm{aa}}$, Howard Quigley ${ }^{\mathrm{e}}$, Lain E. Pardo ${ }^{\mathrm{ab}}$, Joel C. Sáenz ${ }^{\mathrm{ac}}$, Khiavett Sanchez ${ }^{\mathrm{b}}$, John Polisar ${ }^{\mathrm{c}}$

a School of the Environment, Washington State University, Pullman, WA 99163, USA

${ }^{\mathrm{b}}$ El Colegio de la Frontera Sur (ECOSUR), Department of Biodiversity Conservation, Lerma, Mexico

${ }^{\mathrm{c}}$ Wildlife Conservation Society, 2300 Southern Blvd, The Bronx, NY 10460, USA

d División Académica de Ciencias Biológicas, Universidad Juárez Autónoma de Tabasco, Villahermosa, Tabasco 86039, Mexico

${ }^{\mathrm{e}}$ Panthera, 8 West 40th Street, 18th Floor, New York, NY, USA

${ }_{\mathrm{f}}^{\mathrm{E}}$ Environmental Research Institute, University of Belize, Price Centre Road, Belmopan, Belize

${ }^{g}$ Global Wildlife Conservation, P.O. Box 129, Austin, TX 78767, USA

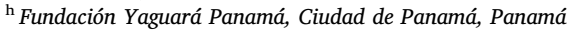

${ }^{i}$ Fundación en Ciencias para el Estudio y Conservación de la Biodiversidad, Tegucigalpa, Honduras

${ }^{\mathrm{j}}$ School of Biology, University of Costa Rica, 11501-2060 San José, Costa Rica

${ }^{\mathrm{k}}$ People \& Fauna Program, Confraternidad Guanacasteca, 50503, Guanacaste, Costa Rica

${ }^{1}$ Coastal Jaguar Conservation, 126-3100, Santo Domingo, Heredia, Costa Rica

${ }^{\mathrm{m}}$ Smithsonian Tropical Research Institute, Balboa, Panama

${ }^{\mathrm{n}}$ University of Texas, Department of Geography and the Environment, Austin, TX, USA

${ }^{\circ}$ Natura y Ecosistemas Mexicanos, A. C. Plaza San Jacinto, Ciudad de México, Mexico

${ }^{\mathrm{p}}$ Facultad de Ciencias, Universidad Nacional Autónoma de México, Av. Universidad 3000, Circuito exterior S/N. Ciudad Universitaria, Mexico City 04510, Mexico

${ }^{\mathrm{q}}$ Costa Rica Wildlife Foundation, Barrio Escalante, 10101 San José, Costa Rica

${ }^{\mathrm{r}}$ Department of Applied Ecology, North Carolina State University, Raleigh, NC, USA

${ }^{\mathrm{s}}$ ProCAT Colombia/Internacional, Las Alturas, Coto Brus, Puntarenas, Costa Rica

${ }^{\mathrm{t}}$ CONANP, Calle Misael Nuñez Acosta \#61, Fraccionamiento Magisterio Democrativo, Oaxaca 70014, Mexico

${ }^{\mathrm{u}}$ Wildlife Sciences, University of Goettingen, Goettingen, Germany, School of Environment, Natural Resources and Geography, Bangor University, Bangor, United Kingdom

${ }^{\mathrm{v}}$ Department of Forestry and Environmental Resources, NC State University, Raleigh, NC, USA

${ }^{\mathrm{w}}$ Instituto Nacional de conservación y Desarrollo forestal, áreas protegidas y vida silvestres, Tegucigalpa, Honduras

${ }^{\mathrm{x}}$ Bioconciencia A.C., Mexico City, Mexico

${ }^{\text {y }}$ Arizona Center for Nature Conservation/Phoenix Zoo, Phoenix, AZ 85008, USA

${ }^{\mathrm{z}}$ Dirección de Reservas Estatales Balam-Kú y Balam-Kin, Secretaría de Medio Ambiente, Biodiversidad y Cambio Climático, Fracciorama 2000, San Francisco de Campeche, Campeche, Mexico

${ }^{\text {aa }}$ Lyman Briggs College and the Department of Fisheries and Wildlife, Michigan State University, East Lansing, MI 48825, USA

${ }^{\mathrm{ab}}$ School of Natural Resource Management, Nelson Mandela University, George, South Africa

${ }^{a c}$ Instituto Internacional en Conservación y Manejo de Vida, Universidad Nacional, Heredia, Costa Rica

\footnotetext{
* Corresponding author.

E-mail address: daniel.thornton@wsu.edu (D. Thornton).
} 


\section{A R T I C L E I N F O}

\section{Keywords:}

Distribution modelling

Large herbivores

Population decline

Neotropics

Range decline

White-lipped peccaries

\begin{abstract}
A B S T R A C T
Large mammalian herbivores are experiencing population reductions and range declines. However, we lack regional knowledge of population status for many herbivores, particularly in developing countries. Addressing this knowledge gap is key to implementing tailored conservation strategies for species whose population declines are highly variable across their range. White-lipped peccaries (Tayassu pecari) are important ecosystem engineers in Neotropical forests and are highly sensitive to human disturbance. Despite maintaining a wide distributional range, white-lipped peccaries are experiencing substantial population declines in some portions of their range. We examined the regional distribution and population status of the species in Mesoamerica. We used a combination of techniques, including expert-based mapping and assessment of population status, and data-driven distribution modelling techniques to determine the status and range limits of white-lipped peccaries. Our analysis revealed declining and highly isolated populations of peccaries across Mesoamerica, with a range reduction of $87 \%$ from historic distribution and $63 \%$ from current IUCN range estimates for the region. White-lipped peccary distribution is affected by indices of human influence and forest cover, and more restricted than other sympatric large herbivores, with their largest populations confined to transboundary reserves. To conserve white-lipped peccaries in Mesoamerica, transboundary efforts will be needed that focus on both forest conservation and hunting management, increased cross-border coordination, and reconsideration of country and regional conservation priorities. Our methodology to detail regional white-lipped peccary status could be employed on other poorly-known large mammals.
\end{abstract}

\section{Introduction}

Globally, many terrestrial mammals are experiencing population declines and range contractions (Ceballos and Ehrlich, 2002; Ceballos et al., 2017). Mid and large-sized mammals may be particularly vulnerable (Laliberte and Ripple, 2004), with population losses leading to range contractions of $>40 \%$ for the majority of species and exceeding $80 \%$ in some cases (Ceballos et al., 2017). However, not all populations of large mammals are equally vulnerable. Rather, mammal range decline occurs more often in areas of high human influence (highly transformed or populous landscapes), due to the reliance of largebodied mammals on extensive areas of undisturbed habitat and lack of hunting or persecution (Laliberte and Ripple, 2004; Yackulic et al., 2011; Ripple et al., 2016; Wolf and Ripple, 2017). Range contraction for large mammals is also more likely in certain biome types, areas that are outside of designated protected areas, or areas located at the edge of the range (Yackulic et al., 2011). Despite threats to mammal persistence, many of the species currently thought to be experiencing declines are poorly studied. Consequently, little is known about distribution, ecology, and population trends of these species, particularly in developing regions of the world (Ripple et al., 2015).

Filling this knowledge gap is critical, as regional evaluations of distribution or population status can help target conservation interventions to areas where species experience variable declines and range retractions. That knowledge can provide guidance for local and regional conservation status changes that reflect the situation in particular portions of a species' range (Miller et al., 2007), rather than relying on coarse global status assessments to provide local guidance. In some cases, a species' global status may contrast with its status at national and regional levels, almost inhibiting elevated conservation prescriptions in emergency situations (De la Torre et al., 2017). Large-scale, regional assessments are therefore key to informing conservation strategies for poorly known mammals.

Large mammalian carnivores receive the most attention and conservation investment to help document and mitigate population losses and range contraction. However, more than half of the world's large mammalian herbivores are threatened with extinction or have currently declining populations (Ripple et al., 2015). Large herbivores and frugivores play key roles in ecosystem processes through the activities of plant consumption and seed dispersal and predation (e.g., Fragoso, 1999; O'Farrill et al., 2013; Galetti et al., 2015); thus, extinction and decline of large herbivores has ecosystem-level consequences. For example, loss of herbivorous mammals due to hunting in Neotropical forests alters rates of seed dispersal and predation, plant functional traits, and carbon storage (Wright et al., 2000; Kurten et al., 2015; Peres et al., 2016).
White-lipped peccaries (Tayassu pecari) are a wide-ranging social ungulate that inhabits Neotropical lowland forest. This species plays a key role in Neotropical forests as an important seed predator and disperser, food source for large predators and human communities, and ecosystem engineer of water sources (Altrichter 2005; Beck, 2005; Beck et al., 2010; Foster et al., 2010). White-lipped peccaries have an extensive range, with their southern range limit occurring in Argentina, a large core population in Amazonia, and the northern range extent in Central America and southern Mexico (for simplicity we hereafter refer to this northern range extent as 'Mesoamerica'; Supplementary Fig. 1). Due to their social behavior and grouping-based anti-predatory defense, white-lipped peccaries are highly sensitive to hunting pressure (ReynaHurtado et al., 2010; Keuroghlian et al., 2013; Nogueira et al., 2015; Briceňo-Méndez et al., 2016). Their large area needs, and reliance on widely dispersed fruit and water sources, also makes this species highly vulnerable to forest loss and fragmentation (Altrichter et al., 2012).

A range-wide, expert-based mapping exercise developed in 2005 suggested that white-lipped peccaries had been extirpated from $21 \%$ of their historic range, with low probability of long-term survival in another $48 \%$ of their current range (Altrichter et al., 2012). Despite this sensitivity, white-lipped peccaries are only classified as Vulnerable by the IUCN due to a wide distribution range and continued persistence in many protected areas, but with recognition that the species is undergoing substantial declines in certain portions of the range (Keuroghlian et al., 2013). In particular, substantial losses of populations may be occurring at the range edges in southern South America and Mesoamerica (Altrichter et al., 2012) and some country-level conservation status listings reflect this increased concern (white-lipped peccaries are listed as critically endangered in Nicaragua, and endangered in Mexico, Costa Rica, and Panama). Thus, status in the peripheral range segments may be much worse than the "global" population, and represent a mismatch in conservation priorities with consequences for the longterm persistence of peccaries in many countries.

Due to the difficulties of studying a wide-ranging and elusive Neotropical forest mammal, only a handful of empirical studies on white-lipped peccary population and habitat ecology have been published. These studies focused primarily on habitat use, diet, movement, and response to hunting, and were conducted at relatively small scales (e.g., Altrichter et al., 2001; Fragoso, 1998; Keuroghlian et al., 2004; Reyna-Hurtado et al., 2009; Reyna-Hurtado et al., 2012). Obtaining a regional perspective on peccary populations is difficult because of a lack of empirical information, and because the range of white-lipped peccary cuts across 18 countries, with distinct conservation and management systems (Thornton and Branch, 2019). Thus, regional knowledge of population limits or status requires bringing together a diverse 
set of information and knowledge across multiple countries in a systematic fashion. Although Altrichter et al. (2012) mapped Peccary Conservation Units and provided needed information on range reduction, their analysis was based solely on expert opinion and focused at the scale of the entire range as opposed to regions of highest threat. In contrast, the present work aims to provide finer-grained information on regional white-lipped peccary distribution and population status within the northern range limit of Mesoamerica. The persistence of whitelipped peccaries in Mesoamerica is particularly challenging as the region contains relatively poor protected area coverage (Rodrigues et al., 2004; Jenkins and Joppa, 2009), with protected areas heavily impacted by human activities such as hunting and other forms of resource extraction. Moreover, Mesoamerica is experiencing overall declines in forest cover both within and outside of protected areas (Olsoy et al., 2016). Although the focus of our analysis in on white-lipped peccary, another large-bodied social ungulate, the collared peccary (Pecari tajacu), also inhabits the region. Despite being impacted by hunting and habitat loss (Thornton et al., 2011; Briceňo-Méndez et al., 2016), collared peccaries appear to be less affected by such disturbances (Peres, 1996; Keuroghlian et al., 2004) though this perception has not been assessed at the regional scale. Given the biological similarities between the species, we include collared peccaries in some of the analyses in this paper to provide a comparison between the patterns seen for whitelipped peccaries with that of another large, social ungulate. Such comparisons help to inform if white-lipped peccaries are especially vulnerable in the region, or if their response is largely reflective of more widespread patterns seen in other large herbivores.

The overall objective of this study is to assess the status of whitelipped peccary populations in Mesoamerica. We do this through use of an expert questionnaire and through modelling peccary distribution via a combination of data sources, including expert-based opinion, presence data, and detection/non-detection data from a camera-trapping meta-dataset derived from numerous researchers across the region. This combination of sources allows us to assess population status, regional distribution, and how boundaries of currently extant populations and suitable habitat relate to country borders. We test several predictions: 1) Given recent increases in human pressure in the region, and our focused regional mapping, we predict that white-lipped peccary populations are decreasing regionally in Mesoamerica, and that the total suitable habitat and area occupied by this species is smaller than previous work suggests. 2) We predict that suitable habitat and area of occupancy for collared peccaries will be more extensive than for whitelipped peccaries at a regional scale, given local evidence of differential vulnerability of the two species. 3) Finally, we predict that regional distribution of white-lipped peccaries will be influenced primarily by forest cover and metrics of human disturbance.

\section{Methods}

\subsection{Study area}

The Mesoamerican study area encompassed the historic distribution of white-lipped peccary in Mexico and Central America, and extended from southeastern Mexico through Panama (Fig. 1A). This region includes a diversity of ecosystems, including dry and wet tropical forest, pine-oak forests, wetlands, and cloud forest (Olson and Dinerstein, 2002). Conversion of natural habitats for pasture and agriculture is the key driver of habitat loss (Armenteras et al., 2017). Recent forest cover loss within and outside of protected areas remains a concern, occurring at high rates in comparison to other locations in the Americas (Olsoy et al., 2016). High human population densities in many parts of Mesoamerica lead to other impacts on habitats in the region, including hunting and illegal timber extraction. Protected areas in the study region tend to be small and relatively isolated, with the exception of several major, transboundary protected area complexes that maintain large areas of intact forest cover.

\subsection{Expert-based analysis}

In June 2016, we sent a questionnaire to experts in each of the seven countries of our study region (Mexico, Belize, Guatemala, Honduras, Nicaragua, Costa Rica, and Panama; white-lipped peccaries are already extirpated from El Salvador; Reyna-Hurtado et al., 2017). We requested that each expert coordinate with other national researchers to compile information regarding populations of white-lipped peccary in their country. Criteria for selecting experts included extensive in-country field research experience, possession of data on white-lipped peccary abundance and distribution, and ability to engage with fellow-researchers in their country.

This questionnaire required the expert coordinators and their incountry contacts to work together to review and compile information related to current population boundaries of white-lipped peccaries within each country. The questionnaire also asked for estimates of population size (within categories of $0-1000,1000$ to $5000,>5000$ ), estimates of average group size $(0-50,50-100,100-300,>300)$, and whether the population was perceived to be stable, increasing or decreasing (See Supplementary Methods for example of questionnaire).

We brought all expert coordinators together for a symposium held as part of the $X X$ Congress of the Mesoamerican Society for Biology and Conservation in Belize City on August 24th, 2016 (Reyna-Hurtado et al., 2017). Information from the questionnaires was compiled across countries, and expert coordinators engaged in a mapping exercise to delineate polygons of current range limits within each country, based on the information they had gathered. These polygons were translated into shapefiles in GIS to calculate total area of current range limits. We compared these range limits with historic limits, as well as limits that were delineated for Mesoamerica by Altrichter et al. (2012) in their previous range-wide, expert-based mapping exercise, and current IUCN range polygons (IUCN, 2019).

\subsection{Presence-only distribution modelling}

Expert-based knowledge of range limits has some limitations, such as subjective biases, lack of knowledge of certain areas, and an inability to account for uncertainty (McBride et al., 2012). Therefore, we created a distribution model based on confirmed detections to better understand distribution and habitat suitability patterns for white-lipped peccaries across our Mesoamerican landscape. This method allows us to make use of a wide variety of data sources on white-lipped peccaries in order to estimate relative habitat suitability across the region. Because similar field methods detected both collared and white-lipped peccaries, we simultaneously conducted a similar exercise for the collared peccary so that we would have a direct comparison with another large social ungulate in the region. We collected presence locations for whitelipped peccaries and collared peccaries from a variety of sources, including camera-trap data, published literature and reports, and Global Biodiversity Information Facility databases (the latter two sources contained presence information obtained from a variety of methods, including line-transect data, and ad hoc direct and indirect observations). Presence data were thinned to only include one presence record within a $5.6 \mathrm{~km}$ radius $\left(100 \mathrm{~km}^{2}\right.$ area) using the spThin package in $\mathrm{R}$ (Aiello-Lammens et al., 2015), to adjust for sampling bias that is a common problem with presence-only analysis (Kramer-Schadt et al., 2013). We tried smaller thinning radii ( $1.8 \mathrm{~km}$ and $2.8 \mathrm{~km})$ so that we incorporated more presence records but found resultant models to be unrealistically constrained to areas of greater sampling such as those with a large number of camera-trapping records. We only included presence records collected after 1990 (with $>80 \%$ of records from post-2000) as we were interested in modelling suitability of recent time periods. This process resulted in 228 presence points for white-lipped peccary and 317 presence points for collared peccary (Supplementary Fig. 2). We used Maxent modelling to develop habitat suitability maps and examine the influence of environmental drivers on suitability for 


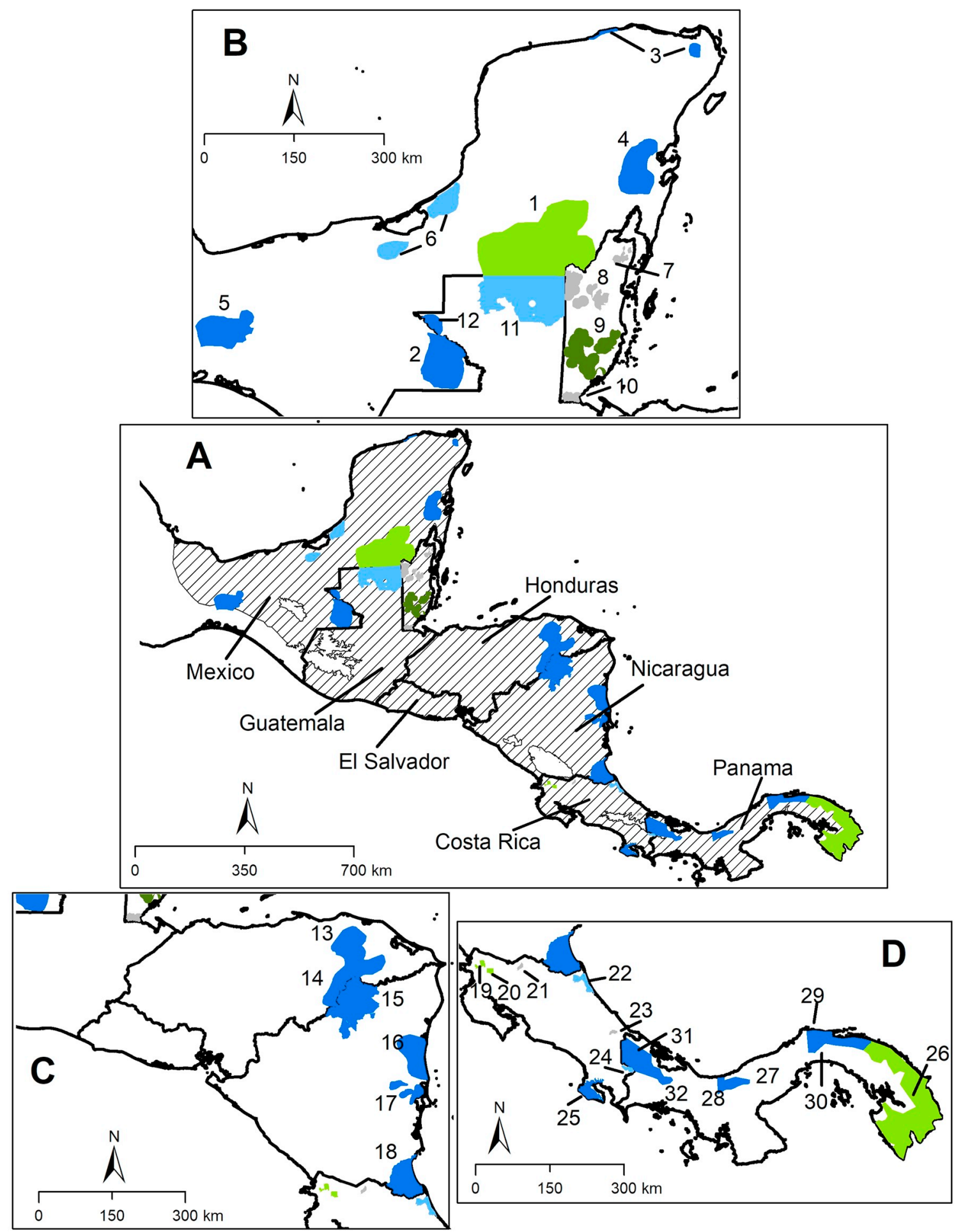

Fig. 1. Maps of extant white-lipped peccary populations in Mesoamerica based on expert opinion. A) Map for the entire Mesoamerican study region. Currently extant populations are colored according to their population status as estimated by experts: Dark green $=$ increasing, light green $=$ stable, dark blue $=$ decreasing, light blue $=$ probably decreasing, gray $=$ unknown. Hatching indicates the historical distribution of the species. B-D provide zoomed in images for northern, central, and southern portions of the study region, respectively. Numbers of each population correspond to the first column in Table 1 . These populations are: $1=$ Calakmul, $2=$ Montes Azules, $3=$ Dzilam-Eden, $4=$ Sian Kaan, $5=$ Chimalapas, $6=$ Laguna de Terminos, $7=$ NE Belize, $8=$ Rio Bravo $/$ Gallon Jug, $9=$ Maya Mountains, $10=$ Sarstoon-Temash, $11=$ Eastern Maya Biosphere, $12=$ Sierra del Lacandon, $13=$ Rio Plantano/Tawahka/Consejos, $14=$ Patuca, $15=$ Bosawas, $16=$ Awaltara/Prinzu, $17=$ Wawashang, $18=$ Indio Maiz, $19=$ Guanacaste/Santa Rosa, $20=$ Rincón de la Vieja, $21=$ Caňa Negro, $22=$ Tortuguero, $23=$ Hitoy Cerere, 24 = Las Tablas, $25=$ Osa, $26=$ Darien, $27=$ Santa Fe, $28=$ Donoso, $29=$ Portobelo, $30=$ Chagres, $31=$ La Amistad, $32=$ Palo Seco. (For interpretation of the references to colour in this figure legend, the reader is referred to the web version of this article.) 
each species via response curves. The environmental variables included in this analysis were the human influence index in the year 2000 (which incorporates the effect of population density, human land use and infrastructure and human access; WCS, 2005), forest cover in year 2000 (Hansen et al., 2013), ecoregion categorization (categories included moist tropical forest, dry tropical forest, pine-oak forest, thorn-scrub, and mangroves), elevation, distance from the nearest protected area, and distance to nearest stream. We choose to use data for forest cover and human influence in the year 2000 to better match the midpoint of the timeframe for our presence records. Additional details on these variables, and the Maxent modelling process, are given in Supplementary Methods.

\subsection{Occupancy models}

Although presence-only modelling techniques can accurately model distributional limits in different contexts (e.g., Searcy and Schaffer, 2016; Proosdij et al., 2016; West et al., 2016), and have advantages in that they allow the use of presence records from a variety of sources (especially important for elusive tropical mammals) and across large spatial extents, these techniques have drawbacks such as vulnerability to sampling bias, modelling of suitability instead of probability of presence, and a failure to account for detection probabilities (GuilleraArroita et al., 2015). To address some of these limitations, and provide an additional perspective on peccary distribution in Mesoamerica, we also performed region-wide occupancy modelling (MacKenzie et al., 2002). Occupancy modelling is advantageous as it allows for the adjustment of distribution patterns based on detection probability and provides estimates of the absolute probability of presence, but is limited to only datasets for which detection histories can be generated (in our case, only camera-trapping records where we had access to the primary datasets). We collated camera-trapping datasets from across our Mesoamerican study region for the creation of detection histories for both peccary species. The final dataset was composed of 53 distinct camera surveys (Supplementary Fig. 3) that totaled 1876 camera stations. Studies included in our analysis spanned the time frame of 2005 to 2017 (with $88 \%$ of the studies conducted 2010 or later), and we only included studies with at least 10 camera stations. Although these studies varied in their exact designs, the basic features of the studies were similar, with cameras placed along movement pathways and primarily targeted for large bodied mammals. We created detection histories for each camera station by determining detection/non-detection over every 10 days of camera survey. We limited each survey to a maximum of 120-day sampling period.

We analyzed occupancy patterns at the scale of a $36 \mathrm{~km}^{2}$ hexagonal cell. Analysis at the level of the $36 \mathrm{~km}^{2}$ cell provides a coarser-grain measurement of drivers of species distribution (MacKenzie et al., 2017), and for the wide-ranging species here, may better reflect true patterns of occupancy. The $36 \mathrm{~km}^{2}$ size was chosen because it falls toward the low end of estimates for white-lipped peccary home range size from Mesoamerica (Carrillo et al., 2002; Reyna-Hurtado et al., 2009; Moreira-Ramírez et al., 2018). For analyses at the cell level, we combined detections for all cameras that fell within a grid cell for each 10day period to record detection histories. We tested the influence of several covariates that we suspected would drive detection or occupancy patterns of our species. We considered the number of cameras within a $36 \mathrm{~km}^{2}$ cell, season of survey (wet vs. dry), year of survey, effort (\# of days all cameras were active within a cell), and country of the survey (to account for unmodelled differences in survey techniques or regional abundance) as our detection covariates. Occupancy variables considered were forest cover in the year 2010 (Hansen et al., 2013), a human footprint layer for the year 2015 (similar to the human influence layer used in Maxent modelling, and incorporating human access, forest cover, permanent lights, human population density, and forest fires; Hugo Ramos, unpublished data), elevation, distance to edge of protected area, and distance to streams. We used covariates for

Table 1

Estimated population size, group size, and population trend of white-lipped peccary populations from seven countries of Mesoamerica, based on expert opinion.

\begin{tabular}{|c|c|c|c|c|c|}
\hline Map $\#^{\mathrm{a}}$ & Country & Populations & Population size (range) & Group size (range) & Trend \\
\hline 1 & Mexico & Calakmul Biosphere Reserve & $1000-5000$ & $<50$ & Stable \\
\hline 2 & Mexico & Montes Azules Biosphere Reserve & $1000-5000$ & $50-100$ & Decreasing \\
\hline 3 & Mexico & Dzilam-Eden & $1-1000$ & $<50$ & Decreasing \\
\hline 4 & Mexico & Sian Kaan Biosphere Reserve & $1-1000$ & $?$ & Decreasing \\
\hline 5 & Mexico & Chimalapas region & $1000-5000$ & $<50$ & Decreasing \\
\hline 6 & Mexico & Area de Protección de Flora y Fauna Laguna de Terminos & $1-1000$ & $<50$ & Probably decreasing \\
\hline 7 & Belize & Northeastern Belize & $1-1000$ & Unknown & Unknown \\
\hline 8 & Belize & Rio Bravo and Gallon Jug Private Conservation Areas & Unknown & Unknown & Unknown \\
\hline 9 & Belize & Maya Mountains Massif & Unknown & $50-100$ & Increasing \\
\hline 10 & Belize & Sarstoon-Temash National Park & $1-1000$ & Unknown & Unknown \\
\hline 11 & Guatemala & Eastern Maya Biosphere Reserve & $1000-5000$ & $50-100$ & Probably decreasing \\
\hline 12 & Guatemala & Sierra del Lacandon National Park & $1-1000$ & $<50$ & Decreasing \\
\hline 13 & Honduras & Rio Platano Biosphere Reserve, Tawahka, Consejos Territoriales & $1000-5000$ & $<50$ & Decreasing \\
\hline 14 & Honduras & Patuca National Park & $1-1000$ & $<50$ & Decreasing \\
\hline 15 & Nicaragua & Bosawas Biosphere Reserve & $1-1000$ & $<50$ & Decreasing \\
\hline 16 & Nicaragua & Awaltara, Prinzu Auhya Un, and Prinzu Awala territories & $1-1000$ & $50-100$ & Decreasing \\
\hline 17 & Nicaragua & Wawashang & $1-1000$ & $<30$ & Decreasing \\
\hline 18 & Nicaragua & Indio Maiz & $1-1000$ & $50-100$ & Decreasing \\
\hline 19 & Costa Rica & Guanacaste and Santa Rosa National Park & $1-1000$ & $<50$ & Stable \\
\hline 20 & Costa Rica & Rincón de la Vieja National Park & $1-1000$ & $<50$ & Stable \\
\hline 21 & Costa Rica & Caňo Negro Wildlife Refuge & $1-1000$ & $<50$ & Unknown \\
\hline 22 & Costa Rica & Tortuguero National Park and Barra del Colorado Wildlife Refuge & $1-1000$ & $<50$ & Probably decreasing \\
\hline 23 & Costa Rica & Hitoy Cerere Biological Reserve & $1-1000$ & $<50$ & Unknown \\
\hline 24 & Costa Rica & Las Tablas Protective Zone & $1-1000$ & $50-100$ & Probably decreasing \\
\hline 25 & Costa Rica & Osa Peninsula & $1-1000$ & $50-100$ & Decreasing \\
\hline 26 & Panama & Darien National Park & $1000-5000$ & $50-300$ & Stable \\
\hline 27 & Panama & Santa Fe National Park & $1-1000$ & $<50$ & Decreasing \\
\hline 28 & Panama & Donoso Multiple Use Area & $1-1000$ & $<50$ & Decreasing \\
\hline 29 & Panama & Portobelo National Park & $1-1000$ & $<50$ & Decreasing \\
\hline 30 & Panama & Chagres National Park & $1-1000$ & $<30$ & Decreasing \\
\hline 31 & Panama & Parque Internacional de la Amistad & $1-1000$ & $50-100$ & Decreasing \\
\hline 32 & Panama & Palo Seco Bosque Protector & $1-1000$ & $50-100$ & Decreasing \\
\hline
\end{tabular}


human influence and forest cover that were more recent to better match the time period of the occupancy surveys. We used single season occupancy models to project occupancy probabilities across the Mesoamerican landscape, determine the number of occupied cells and total area occupied, and examine response curves to environmental variables. Additional details of the modelling process are given in Supplementary Methods.

\section{Results}

\subsection{Expert-based analysis}

Our experts identified 32 populations of white-lipped peccaries scattered across seven countries of Mesoamerica (Table 1). Experts classified 22 of the 32 populations $(68.8 \%)$ as decreasing or probably
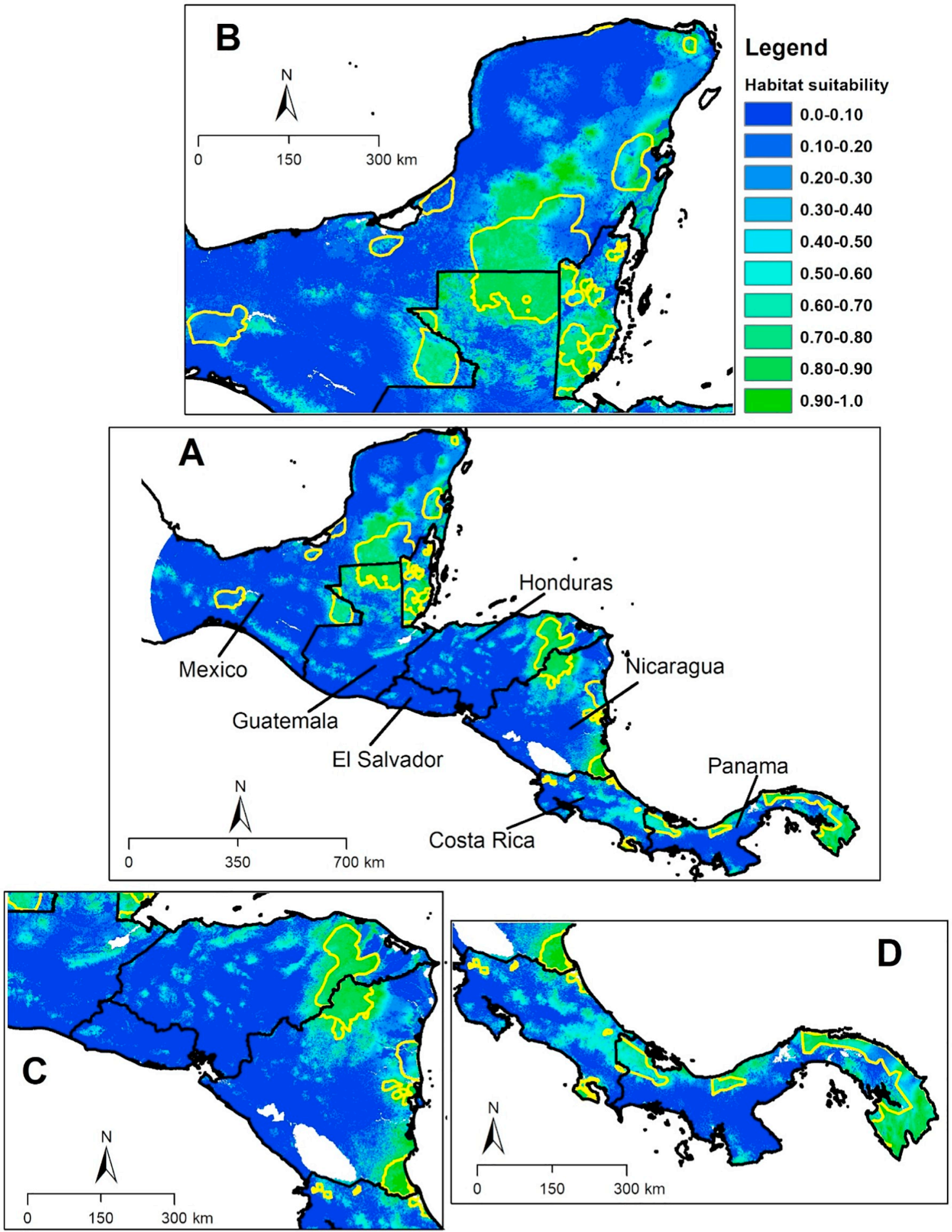

Fig. 2. Habitat suitability maps based on Maxent models for white-lipped peccaries in Mesoamerica. A) Map for the entire Mesoamerican study region. Yellow polygons show location of expert-based opinion on boundaries of currently extant populations of white-lipped peccaries. B-D provide zoomed in images for northern, central, and southern portions of the study region, respectively. (For interpretation of the references to colour in this figure legend, the reader is referred to the web version of this article.) 
decreasing, 5 as unknown (15.5\%), 4 populations as stable $(12.5 \%)$, and only one as increasing (3.2\%). The majority (78\%) of populations were estimated to be fewer than 1000 animals, and in most cases where data were available, current group sizes were estimated to be fewer than 50 animals $(66 \%)$ (Table 1 ). Stable populations or populations $>1000$ individuals were reported only in the Maya Forest (Calakmul Biosphere Reserve in Mexico, Maya Biosphere Reserve in Guatemala), Darien National Park in Panama, and Osa Peninsula of Costa Rica, with increasing populations in the Maya Mountains complex of Belize. According to experts, many other populations are experiencing rapid decreases. Experts indicated that the declines are due to habitat loss, hunting pressure, and loss of connectivity.

According to the expert-based mapping exercise, the 32 populations of white-lipped peccaries in Mesoamerica cover an area of $97,596 \mathrm{~km}^{2}$. This current distribution represents a reduction of $87 \%$ when compared to the historic range (Fig. 1). Further, this current estimate of occupied area is a reduction of $51 \%$ from the previous mapping exercise in 2005 (Altrichter et al., 2012) and a 63\% reduction from the current IUCN range map (which is based largely on the Altrichter mapping exercise, except for two additional population polygons in southeastern Mexico). If we eliminate from consideration any areas designated by the IUCN range map as "Probably Extant", then this reduction is 45\% (Supplementary Fig. 4). The largest discrepancies between our expert-based range map and the previous range maps (Supplementary Fig. 4) are that we estimated a much reduced distribution in Nicaragua and Honduras, particularly northern Honduras and central Nicaragua - both areas of rapid recent deforestation and degradation. In contrast, our expertbased maps predict extra isolated populations in certain areas that were not included in previous maps, particularly in Coastal ecosystems of southeastern Mexico.

\subsection{Presence-only distribution modelling}

Average suitability maps for white-lipped peccaries reveal restricted and isolated pockets of suitable habitat for this species (Fig. 2). Many of the expert-based polygons fall within areas identified as highly suitable based on Maxent models, suggesting general agreement between the two modelling exercises. Exceptions to this agreement include several highly isolated and peripheral populations identified by experts in southeastern Mexico and Costa Rica that appear to contain little suitable habitat. We also note several areas of highly suitable habitat that occur outside expert-based polygons, but these usually fall at the edges of current polygons and thus may represent relatively minor underestimates by experts or overestimates by the Maxent models.

In comparison, collared peccary models have many of the same highly suitable clumps of habitat, but generally have more suitable habitat across the landscape, including many more isolated and diffuse pockets of suitability that occur in more disturbed and fragmented areas of Mesoamerica (Supplementary Fig. 5). Based on evaluation metrics for spatially held out test data, both models were able to accurately discriminate actual presence locations from background locations (see Supplementary Methods). Area-Under-the-Curve values, which range from 0 to 1 (perfect discrimination of presence and background data) were 0.85 for white-lipped peccary models and 0.77 for collared peccary models.

White-lipped and collared peccary habitat suitability were best explained using Maxent settings for response curves that included linear and quadratic features, with a regularization of 1 for white-lipped peccaries and 1.5 for collared peccaries (see Supplementary Methods). Based on jackknife estimates of parameter importance, human influence, forest cover, distance from protected areas, and ecoregion were the most important variables in determining relative suitability for both peccary species. Consistent with the mapping results, both peccary species were influenced in a similar manner by increasing human influence and distance from protected areas, and declining forest cover, but white-lipped peccary suitability was affected more strongly and negatively by these factors (Supplementary Fig. 6).

\subsection{Occupancy models}

Best-fitting cell-level occupancy models for both species included only human footprint index and elevation (Table 2; see Supplementary Results for full list of models tested), with detection models containing country of survey and number of cameras in a cell. Parameter estimates $( \pm \mathrm{SE}$ ) for the best fitting model for white-lipped peccaries were -1.60 (0.26), $0.06(0.50),-1.17$ (1.70) for human influence, elevation, and elevation $^{2}$, respectively; estimates for collared peccaries were -0.76 (0.16), $-0.80(0.40), 0.78(0.39)$, for human influence, elevation, and elevation $^{2}$, respectively. Increasing human footprint exerted a negative impact on both species, but was much more pronounced for whitelipped peccaries (Fig. 3). Conditional occupancy estimates indicated that white-lipped peccaries were predicted to occupy 93.8 (95\% $\mathrm{CI}=76.7-118.6)$ of the 470 hexagonal cells that were sampled. This amounts to an occupancy rate of $0.19(95 \% \mathrm{CI}=0.16-0.25)$. Collared peccaries were predicted to occupy $225(95 \% \mathrm{CI}=201.6-250.8)$ of the 445 hexagonal cells that were sampled, which is a significantly higher occupancy rate of 0.51 (95\% CI $=0.45-0.56)$. There was some evidence of minor overdispersion for white-lipped peccaries (chat $=2.01$ ).

When projecting the best-fit model across the entire Mesoamerican study area, white-lipped peccaries have isolated patches of medium occupancy probabilities that match well with expert-based polygons (Fig. 4). Again, several contiguous areas of predicted occupancy lie across country borders (e.g., Mexico-Guatemala-Belize and HondurasNicaragua). Some mismatch between expert-based polygons and areas of predicted occupancy are apparent in the isolated Mexican populations, similar to the Maxent modelling. Predicted occupancy probabilities for white-lipped peccary do not often exceed 0.50 , even in

Table 2

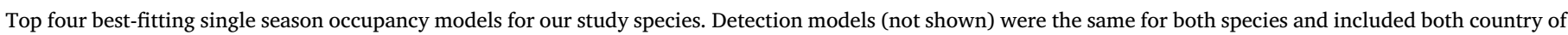

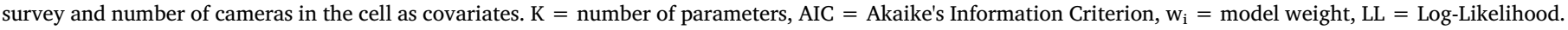

\begin{tabular}{|c|c|c|c|c|}
\hline White-lipped peccary occupancy models & $\mathrm{K}$ & AIC & $\mathrm{w}_{\mathrm{i}}$ & LL \\
\hline Human influence index + elevation + elevation $^{2}$ & 12 & 1025.51 & 0.29 & -500.75 \\
\hline Human influence index & 10 & 1025.91 & 0.24 & -502.93 \\
\hline Human influence index + elevation + elevation $^{2}+$ distance to protected area & 13 & 1027.24 & 0.12 & -500.61 \\
\hline Human influence index + elevation + elevation $^{2}+$ distance to streams & 13 & 1027.51 & 0.11 & -500.76 \\
\hline Collared peccary occupancy models & $\mathrm{K}$ & AIC & $\mathrm{w}_{\mathrm{i}}$ & LL \\
\hline Human influence index + elevation + elevation $^{2}$ & 12 & 2429.88 & 0.28 & -1202.94 \\
\hline Human influence index & 10 & 2430.68 & 0.19 & -1205.338 \\
\hline Human influence index + elevation + elevation $^{2}+$ distance to protected area & 13 & 2431.01 & 0.16 & -1202.503 \\
\hline Human influence index + distance to protected area & 12 & 2431.35 & 0.13 & -1204.677 \\
\hline
\end{tabular}




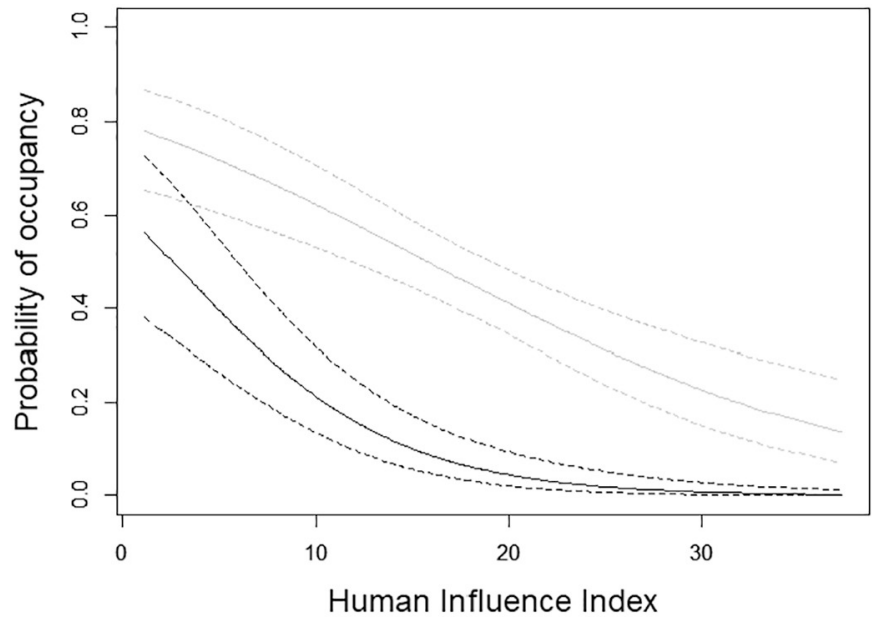

Fig. 3. Occupancy response curves from our best-fitting occupancy model that depict how probability of occupancy changes as a function of the human footprint index. Curves show mean and 95\% confidence intervals for whitelipped peccary (black) and collared peccary (gray). Note that white-lipped peccary probability of occupancy declines rapidly to zero, even at relatively low levels of human disturbance (the index ranges from 0 to 74 for our study region).

areas of extremely low human influence. Based on unconditional occupancy estimates, $2133(95 \% \mathrm{CI}=1610-2766)$ of the 21,490 cells in the entire Mesoamerican region were predicted to be occupied, for an occupancy rate of 0.10 ( $95 \% \mathrm{CI}=0.08-0.12)$. This amounts to a predicted $76,788 \mathrm{~km}^{2}$ of occupied area $(95 \%$ $\mathrm{CI}=57,960 \mathrm{~km}^{2}-99,576 \mathrm{~km}^{2}$ ), which is $\sim 15,000 \mathrm{~km}^{2}$ smaller than the estimate based on expert polygons (after accounting for the expert polygon in southern Mexico that lies outside the area for which we could predict occupancy; see Fig. 4), and a 90\% reduction from historic distribution in the region.

Collared peccaries have a much more diffuse area of predicted occupancy than white-lipped peccaries (Supplementary Fig. 7), which is pattern also reflected in the Maxent models. Collared peccary predicted occupancy extends outside of protected areas and into more heavily disturbed landscapes. Overall, occupancy probabilities were much higher than for white-lipped peccaries, something that is not as apparent from examining habitat suitability patterns from Maxent. Collared peccaries are predicted to occupy 8042 (95\% $\mathrm{CI}=6751-9517)$ cells in the entire study region, for an occupancy rate of 0.37 (95\% CI $=0.31-0.44)$ and a total predicted area of occupancy of $289,512 \mathrm{~km}^{2}\left(243,036 \mathrm{~km}^{2}-342,612 \mathrm{~km}^{2}\right)$.

\section{Discussion}

The global and rapid decline of large herbivore populations necessitates data at appropriately large scales to inform effective conservation planning and management. Our regional analyses reveal that white-lipped peccary populations exist in small and highly isolated patches of habitat in Mesoamerica, and that their populations are in more of a critical condition than previously thought. These results are supported by multiple range mapping exercises involving different analyses, and indicate the advantage of bringing together diverse expertise and datasets from multiple countries for generating regional knowledge of species status. The methods we used here could be employed on other poorly-known large herbivores from developing regions to better assess current population status and limits for species thought to be rapidly declining. Our estimate of area occupied by white-lipped peccaries is a substantial reduction from the previous 2005 estimate (Altrichter et al., 2012) and current IUCN range maps, and a concerning $87-90 \%$ reduction from likely historical distribution in the study region (depending on the analysis considered). This reduction from previous range estimates may be, in part, an artifact of a better definition of area inhabited by the species in our assessment, which focused exclusively on Mesoamerica and included both expertbased and empirical estimates, than previous assessments that focused on the entire range of the species and only included expert opinion. But, at the same time it may also indicate continued rapid population decline in recent decades. Moreover, expert opinion suggests that the majority of the populations remaining in Mesoamerica are declining, with much smaller group sizes than in other areas of the range with less disturbance (Altrichter et al., 2012; Reyna-Hurtado et al., 2016).

The three range-mapping exercises demonstrated that the largest contiguous blocks of habitat for white-lipped peccaries occur in several major transboundary reserves. This includes the Maya Forest of Guatemala, Mexico and Belize, the Rio Platano/Patuca/Bosawas complex of Honduras and Nicaragua, the Indio Maiz and Tortuguero National Park complex of Nicaragua and Costa Rica, and the Darien/Los Katios National Park complex between Panama and Colombia (although we did not model peccary habitat in Colombia, Los Katios National Park is immediately adjacent to Darien). In addition, the La Amistad Biosphere Reserve between Costa Rica and Panama may be another large transboundary patch of habitat, based on occupancy and Maxent modelling, though the area on the Costa Rica side is poorly known and hence was not identified as an extant population in our expert-based assessment. Although population estimates for whitelipped peccaries are highly uncertain, experts estimated that these same transboundary areas likely harbor the highest populations of remaining peccaries. For example, fewer than 2000 white-lipped peccaries may survive in the Calakmul Biosphere Reserve of Mexico, within the northern section of the tri-national Maya Forest (Reyna-Hurtado et al., 2010); however, together with the contiguous forests of the Maya Biosphere Reserve in Guatemala and Rio Bravo in Belize, the entire Maya Forest hosts the largest white-lipped peccary population stronghold in Mesoamerica, with an estimated population of around 5000 individuals. The remote forests of the bi-national complex of the Rio Platano/Patuca and Bosawas Biosphere Reserves in Nicaragua may harbor around 3000 white-lipped peccaries. These large transboundary populations may exist as somewhat separate subpopulations in a larger metapopulations, or could function more as one single population (sensu Biondo et al., 2011).

Outside of the transboundary landscapes, remaining populations of white-lipped peccaries were generally scattered and isolated. Occupancy and suitability mapping show limited occupied or suitable habitat in most of these populations, with experts estimating generally small and declining populations. However, three isolated white-lipped peccary populations in Costa Rica and Belize were either stable or increasing, likely due to the efficacy of conservation interventions in these areas (i.e., little habitat loss, limited hunting). These stable populations may be areas to focus on in terms of enhancing connectivity with surrounding populations, to benefit long-term meta-population persistence. However, we emphasize that preservation of the largest blocks of habitat, those in transboundary landscapes, will be the most important for maintaining larger white-lipped peccary populations that can persist in the coming decades.

The fact that all three modelling exercises, which used different datasets and analysis methods, were in general agreement about whitelipped peccary distribution, provides additional support to our findings. In some rare cases, the occupancy and/or Maxent modelling revealed areas of potential distribution that are currently outside existing expertbased polygons. These areas may represent landscapes where there are suitable conditions but no current peccaries due to historic or other factors, or areas where there are good conditions but limited knowledge. Such areas should be targeted for future surveys (e.g., the large swaths of mid-suitability in southeastern Costa Rica that are outside any expert based polygons). In other cases, several peripheral and isolated expert-based polygons appeared to contain little suitable habitat or had 

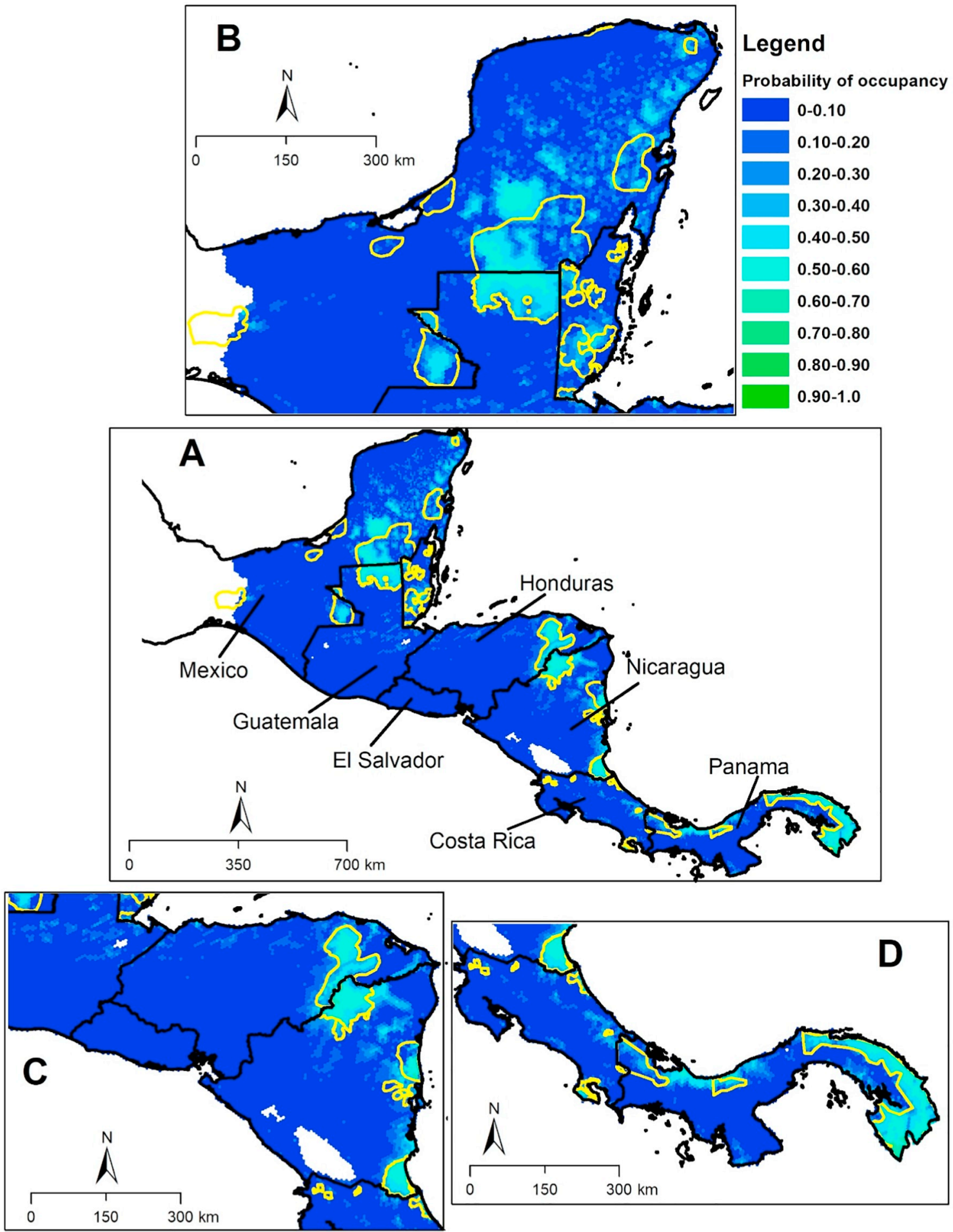

Fig. 4. Probability of occupancy projected across our entire study region for white-lipped peccaries, based on the best-fitting single season occupancy model. A) shows the entire Mesoamerican study region with B-D depicting zoomed in images for northern, central, and southern portions of the study region, respectively. In general, white-lipped peccaries have low-medium probabilities of occupancy across the region. Large contiguous patches of medium occupancy probabilities are found concentrated in several transboundary regions. Note that our human footprint layer did not extend far enough west in Mexico to encompass the most western polygon delineated by experts, and thus we could not predict occupancy in that area.

relatively low estimated probability of presence (e.g., Laguna de Terminos and Chimalapas populations). These could be populations likely to decline further, or could be areas with unique environments or where we were missing appropriate covariate data to model response. Maxent and occupancy models generally agreed, with the caveat that occupancy models revealed generally mid-low probability of presence across the region that could not be discerned with Maxent models. Maxent models also predicted isolated pockets of high suitability in certain areas where occupancy models suggested low probability of presence, such as central and southeastern Guatemala and northern Honduras. Given that peccaries are likely absent from these regions based on expert knowledge and limited surveys, occupancy models 
might be better reflective of distribution outside of larger pockets of habitat. The methodological approach we outline here will not be applicable to all poorly known large mammals. However, the large number of camera-trapping datasets that are available (e.g., Steenweg et al., 2017), and the degree of local knowledge or records that tends to exist for large mammals, suggests that our approach could be useful for generating better regional knowledge of a wide variety of mammalian species.

Although direct comparisons of white-lipped peccary status with other species are problematic, we found that collared peccaries, another large, hunted herbivore in the Neotropics, had much higher levels of occupancy (occupancy rates were almost 3 times higher for collared peccaries) and a more widespread distribution in Mesoamerica than white-lipped peccaries. Additionally, Baird's tapir (Tapirus bairdii), the largest herbivore in Mesoamerica, has occupancy rates and distribution patterns more similar to collared peccaries (Thornton, unpublished data; Schank et al., 2017). Taken together, these findings suggest that white-lipped peccaries are the most vulnerable large herbivorous mammal in Mesoamerica, and perhaps the most vulnerable large mammal of any kind in the region.

Human influence is a key predictor of range retraction and population decline for large mammals globally (Ripple et al., 2015; Ripple et al., 2016), and was of overriding influence for white-lipped peccaries. Although suitability and occupancy of both collared and whitelipped peccaries declined as human influence/human footprint increased, white-lipped peccaries responded particularly strongly, with occupancy probabilities declining quickly to near zero at fairly low levels of human disturbance (Fig. 3). This likely relates to both the need for large tracts of intact habitat for this wide-ranging species and sensitivity to human hunting (Altrichter et al., 2012; Keuroghlian et al., 2013). Similar results were obtained when modelling group size in this species across all its distribution range with larger groups found in areas far from human communities (Reyna-Hurtado et al., 2016). Targeted and sustained hunting pressure may extirpate entire populations of white-lipped peccaries even from areas of relatively well-preserved forest (for example, in large "ejidos" or communal forests of southern Mexico; Reyna-Hurtado et al., 2010), and likely the combination of targeted hunting and habitat loss is the worst scenario for the conservation of white-lipped peccaries in Mesoamerica. In contrast, collared peccaries were able to maintain higher occupancy and suitability at greater levels of human disturbance, demonstrating that regional distribution was reflective of patterns seen at more local scales, where this species appears somewhat tolerant to fragmentation and human disturbance (e.g., Altrichter and Boaglio, 2004; Michalski and Peres, 2007; Thornton et al., 2011). The greater resilience of collared peccaries could be driven by a more generalist diet than the more specialist white-lipped peccary (Sowls, 1997; Fragoso, 1999) which may lead to smaller home ranges across a great range of habitats, and a slightly higher intrinsic rate of increase (Robinson and Redford, 1986). Collared peccaries may also have a greater tendency for groups to flee when threatened (Peres, 1996; Keuroghlian et al., 2004), which should decrease their vulnerability to human hunting. Their smaller group sizes may also make them less conspicuous to human hunters, and decrease the number that can be killed at any one time. In contrast, large groups of white-lipped peccaries sometimes aggressively face threats (Nogueira et al., 2015) which increases their vulnerability to hunters.

Our data demonstrate the dire status of white-lipped peccaries in Mesoamerica. Of particular concern to the plight of white-lipped peccaries in Mesoamerica is the status of the most important remaining strongholds of peccaries - the Maya Forest of Guatemala, Mexico, and Belize, the Rio Platano/Patuca/Bosawas complex of Honduras and Nicaragua, and the Darien complex in Panama and Columbia. All these forests are under particularly grave threat from human activities. For example, in the past 15 years, wildlands (those areas with limited human influence) have been reduced by $30 \%$ in the Rio Platano/Bosawas complex and by $25 \%$ in the Maya Forest (Hugo Ramos, unpublished data). These two forests are at also at imminent risk of losing their contiguity due to expansion of both sugar cane and cattle ranching.

The critical nature of white-lipped peccary populations in much of Mesoamerica is not always well reflected in their listing status at the country level. Currently, there remains a mix of designations and attention given to the species in those countries, with only 4 of the 7 countries listing white-lipped peccaries as endangered or critically endangered. In some cases, listing status should be reassessed in order to provide proper levels of attention to this species. Accurate listing of a species in national lists (Red Lists, or Endangered Species lists) has ramifications for Environmental Impact Assessments and for the management of subsistence and sport hunting. Although the range reduction we documented is substantial at the regional level, the reduction could be driven by both better methods to document range limits as well as ongoing declines. Thus, additional data collection on regional population trends and range retraction would be beneficial in determining if white-lipped peccaries would be a candidate for uplisting at the regional level based on IUCN criteria.

Our analysis suggests that both local and regional conservation actions will be needed to maintain white-lipped peccary populations. Although maintenance of intact forest cover is obviously of high importance to the species, our analysis reveals the potential impact of hunting and other forms of disturbance independent of forest loss. Conservation actions will have to include working with local indigenous and non-indigenous communities in and around protected areas to better manage legal and illegal harvesting of peccaries, and provide suitable alternatives where historical rates of hunting may no longer be sustainable due to landscape level deforestation dynamics. Given the transboundary nature of many of the largest peccary populations, coordinated, large-scale, transboundary conservation efforts in Mesoamerica also will be needed to help ensure the long-term persistence of white-lipped peccaries. Research and conservation efforts that span international borders in these areas could aid in habitat, population and connectivity management of this species, and may bring a diverse set of other benefits such as sharing of expertise, pooling of resources, and more accurate population/distribution data (Kark et al., 2015; Vasilijević et al., 2015; Bischof et al., 2016; Gervasi et al., 2016). The fact that protected areas tend to be clustered near borders in the Americas (Thornton et al., in press), including several transboundary complexes in this analysis, should aid coordinated efforts within the framework of protected areas management. Moreover, similarities in country-level conservation listing status of white-lipped peccaries would likely enhance mechanisms for coordinated management, which may be particularly important for species with wide-ranging movements (Thornton and Branch, 2019). Although these transboundary regions are perhaps most important for white-lipped peccaries, they are also areas of high occupancy/suitability for other large mammals, including collared peccaries (Supplementary Figs. 5 and 7), tapirs (Schank et al., 2017), and jaguars (Rabinowitz and Zeller, 2010), and thus conservation efforts would benefit multiple landscape species. Finally, increased public awareness of the plight of white-lipped peccaries, and its ecological significance, should be elevated to bring additional attention to this highly threatened symbol of national and regional patrimony.

\section{CRediT authorship contribution statement}

Daniel Thornton:Conceptualization, Methodology, Formal analysis, Writing - original draft, Funding acquisition.Rafael Reyna:Conceptualization, Methodology, Formal analysis, Writing original draft, Funding acquisition.Lucy Perera-Romero: Methodology, Formal analysis, Investigation.Jeremy Radachowsky: Conceptualization, Writing - review \& editing, Funding acquisition.Mircea G. Hidalgo-Mihart:Investigation, Writing - review \& editing.Rony Garcia:Investigation, Writing - review \& editing. Roan McNab:Investigation, Writing - review \& editing.Lee 
Mcloughlin:Investigation, Writing - review \& editing.Rebecca Foster: Investigation, Writing - review \& editing.Bart Harmsen:Investigation, Writing - review \& editing.José F. Moreira-Ramírez:Investigation, Writing - review \& editing.Fabricio Diaz-Santos:Investigation, Writing review \& editing.Christopher Jordan:Investigation, Writing - review \& editing.Roberto Salom-Pérez:Investigation, Writing - review \& editing.Ninon Meyer:Investigation, Writing - review \& editing.Franklin Castaneda:Investigation, Writing - review \& editing.Fausto Antonio Elvir Valle:Investigation, Writing - review \& editing.Gabriela Ponce Santizo:Investigation, Writing - review \& editing.Ronit Amit: Investigation, Writing - review \& editing.Stephanny Arroyo-Arce: Investigation, Writing - review \& editing.lan Thomson:Investigation, Writing - review \& editing.Ricardo Moreno:Investigation, Writing - review \& editing.Cody Schank:Investigation, Writing - review \& editing.Paulina Arroyo-Gerala:Investigation, Writing - review \& editing.Horacio V. Bárcenas:Investigation, Writing - review \& editing. Esteben Brenes-Mora:Investigation, Writing - review \& editing.Ana Patricia Calderón:Investigation, Writing - review \& editing.Michael V. Cove:Investigation, Writing - review \& editing.Diego Gomez-Hoyos: Investigation, Writing - review \& editing.José González-Maya: Investigation, Writing - review \& editing.Danny Guy:Investigation, Writing - review \& editing.Gerobuam Hernández Jiménez: Investigation, Writing - review \& editing.Maarten Hofman: Investigation, Writing - review \& editing.Roland Kays:Investigation, Writing - review \& editing.Travis King:Investigation, Writing - review \& editing.Marcio Arnoldo Martinez Menjivar:Investigation, Writing - review \& editing.Javier de la Maza:Investigation, Writing - review \& editing.Rodrigo León-Pérez:Investigation, Writing - review \& editing. Victor Hugo Ramos:Investigation, Writing - review \& editing.Marina Rivero:Investigation, Writing - review \& editing.Sergio RomoAsunción:Investigation, Writing - review \& editing.Rugieri JuárezLópez:Investigation, Writing - review \& editing.Alejandro Jesús-de la Cruz:Investigation, Writing - review \& editing.J. Antonio de la Torre: Investigation, Writing - review \& editing.Valeria Towns:Investigation, Writing - review \& editing.Jan Schipper:Investigation, Writing - review \& editing.Hector Orlando Portillo Reyes:Investigation, Writing - review \& editing.Adolfo Artavia:Investigation, Writing - review \& editing. Edwin Hernández-Perez:Investigation, Writing - review \& editing. Wilber Martinez:Investigation, Writing - review \& editing.Gerald R. Urquhart:Investigation, Writing - review \& editing.Howard Quigley: Conceptualization, Writing - review \& editing.Lain E. Pardo: Investigation, Writing - review \& editing.Joel C. Sáenz:Investigation, Writing - review \& editing.Khiavett Sanchez:Investigation, Writing review \& editing.John Polisar:Conceptualization, Investigation, Writing - review \& editing.

\section{Declaration of competing interest}

The authors declare that they have no known competing financial interests or personal relationships that could have appeared to influence the work reported in this paper.

\section{Acknowledgements}

We thank the US Fish and Wildlife Service Central America program for providing funding for this work. We also thank the many individuals, organizations, and communities that assisted in the collection of the camera-trapping records used in our analysis. We thank the Wildlife Conservation Society for funding and supporting the Belize Symposium and El Colegio de la Frontera Sur of Mexico for support on the writing and analyses phase.

\section{Appendix A. Supplementary data}

Supplementary data to this article can be found online at https:// doi.org/10.1016/j.biocon.2020.108410.

\section{References}

Aiello-Lammens, M.E., Boria, R.A., Radosavljevic, A., et al., 2015. spThin: an R package for spatial thinning of species occurrence records for use in ecological niche models. Ecography 38, 541-545.

Altrichter, M., Boaglio, G.I., 2004. Distribution and relative abundance of peccaries in the Argentine Chaco: associations with human factors. Biol. Conserv. 116, 217-225.

Altrichter, M., Carillo, E., Sáenz, J., Fuller, T.K., 2001. White-lipped peccary (Tayassu pecari, Artiodactyla: Tayassuidae) diet and fruit availability in a Costa Rican rain forest. Revista de Biologia Tropical 49, 1183-1192.

Altrichter, M., Taber, A., Beck, H., et al., 2012. Range-wide declines of a key neotropical ecosystem architect, the near threatened white-lipped peccary Tayassu pecari. Oryx 46, 87-98.

Altrichter, M., 2005. The sustainability of subsistence hunting of peccaries in the Argentine Chaco. Biological Conservation 126, 351-362.

Armenteras, D., Espelta, J.M., Rodríguez, N., Retana, J., 2017. Deforestation dynamics and drivers in different forest types in Latin America: three decades of studies (1980-2010). Glob. Environ. Chang. 46, 139-147.

Beck, H., 2005. Seed predation and dispersal by peccaries throughout the neotropics and its consequences: a review and synthesis. In: Forget, P.-M., Lambert, J.E., Hulme, P.E., Vander Wall, S.B. (Eds.), Seed Fate: Predation, Dispersal and Seedling Establishment. CABI Publishing, Wallingfort, UK, pp. 77-115.

Beck, H., Thebpanya, P., Filaggi, M., 2010. Do Neotropical peccary species (Tayassuidae) function as ecosystem engineers for anurans? J. Trop. Ecol. 26, 1-8.

Biondo, C., Keuroghlian, A., Gongora, J., Miyaki, C.Y., 2011. Population genetic structure and dispersal in the white-lipped peccaries (Tayassu pecari) from the Brazilian Pantanal. J. Mammal. 92, 267-274.

Bischof, R., Broseth, H., Gimenez, O., 2016. Wildlife in a politically divided world: insularism inflates estimates of brown bear abundance. Conserv. Lett. 9, 122-130.

Briceňo-Méndez, M., Naranjo, E.J., Mandujano, S., et al., 2016. Responses of two sympatric species of peccaries (Tayassu pecari and Pecari tajacu) to hunting in Calakmul, Mexico. Tropical Conservation Science 1-11.

Carrillo, E., Saenz, J.C., Fuller, T.K., 2002. Movements and activities of white-lipped peccaries in Corcovado National Park, Costa Rica. Biol. Conserv. 108, 317-324.

Ceballos, G., Ehrlich, P.R., 2002. Mammal population losses and the extinction crisis. Science 296, 904-907.

Ceballos, G., Ehrlich, P.R., Dirzo, R., 2017. Biological annihilation via the ongoing sixth mass extinction signaled by vertebrate population losses and declines. Proc. Natl. Acad. Sci. 114, E6089-E6096.

De la Torre, J.A., Gonzalez-Maya, J.F., Zarza, H., et al., 2017. The jaguar's spots are darker than they appear: assessing the global conservation status of the jaguar (Panthera onca). Oryx 52, 300-315.

Foster, R.J., Harmsen, B.J., Valdes, B., et al., 2010. Food habits of sympatric jaguars and pumas across a gradient of human disturbance. J. Zool. 280, 309-318.

Fragoso, J.M.V., 1998. Home range and movement patterns of white-lipped peccary (Tayassu pecari) herds in the Northern Brazilian Amazon. Biotropica 30, 458-469.

Fragoso, J.M.V., 1999. Perception of scale and resource partitioning by peccaries: behavioral causes and ecological implications. J. Mammal. 80 (3), 993-1003.

Galetti, M., Bovendorp, R., Guevara, R., 2015. Defaunation of large mammals leads to an increase in seed predation in the Atlantic forests. Global Ecology and Conservation 3, 824-830.

Gervasi, V., Broseth, H., Gimenez, O., et al., 2016. Sharing data improves monitoring of trans-boundary populations: the case of wolverines in central Scandinavia. Wildl. Biol. 22, 95-106.

Guillera-Arroita, G., Lahoz-Monfort, J.J., Elith, J., et al., 2015. Is my species distribution model fit for purpose? Matching data and models to applications. Glob. Ecol. Biogeogr. 24, 276-292.

Hansen, M.C., Potapov, P.V., Moore, R., et al., 2013. High-resolution global maps of 21stcentury forest cover change. Science $342,850-853$.

IUCN, 2019. The IUCN red list of threatened species. Version 2019-1. http://www. iucnredlist.org.

Jenkins, C.N., Joppa, L., 2009. Expansion of the global terrestrial protected area system. Biol. Conserv. 142, 2166-2174.

Kark, S., Tulloch, A., Gordon, A., et al., 2015. Cross-boundary collaboration: key to the conservation puzzle. Curr. Opin. Environ. Sustain. 12, 12-24.

Keuroghlian, A., Eaton, D.P., Longland, W.S., 2004. Area use by white-lipped and collared peccaries (Tayassu pecari and Tayassu tajacu) in a tropical forest fragment. Biol. Conserv. 120, 411-425.

Keuroghlian, A., Desbiez, A., Reyna-Hurtado, R., et al., 2013. Tayassu pecari. IUCN Red List of Threatened Species.

Kramer-Schadt, S., Niedballa, J., Pilgrim, J.D., et al., 2013. The importance of correcting sampling bias in MaxEnt species distribution models. Divers. Distrib. 19, 1366-1379.

Kurten, E.L., Wright, S.J., Carson, W.P., 2015. Hunting alters seedling functional trait composition in a neotropical forest. Ecology 96, 1923-1932.

Laliberte, A.S., Ripple, W.J., 2004. Range contractions of North American carnivores and ungulates. Bioscience 54, 123-137.

MacKenzie, D.I., Nichols, J.D., Lachman, G.B., et al., 2002. Estimating site occupancy rates when detection probabilities are less than one. Ecology 83, 2248-2255.

MacKenzie, D.I., Nichols, J.D., Royle, J.A., et al., 2017. Occupancy Estimation and Modelling: Inferring Patterns and Dynamics of Species Occurrence. Elsevier.

McBride, M.F., Garnett, S.T., Szabo, J.K., et al., 2012. Structured elicitation of expert judgments for threatened species assessment: a case study on a continental scale using email. Methods Ecol. Evol. 3, 906-920.

Michalski, F., Peres, C.A., 2007. Disturbance-mediate mammal persistence and abundance-area relationships in Amazonian forest fragments. Conserv. Biol. 21, 
1626-1640.

Miller, R.M., Rodriguez, J.P., Aniskowicz-Fowler, T., et al,, 2007. National threatened species listing based on IUCN criteria and regional guidelines: current status and future perspectives. Conserv. Biol. 21, 684-696.

Moreira-Ramírez, J.F., Reyna-Hurtado, R., Hidalgo-Mihart, M., et al., 2018. White-lipped peccary home-range size in the Maya Forest of Guatemala and México. Chapter 2 In: Reyna-Hurtado, R., Chapman, C.A. (Eds.), Movement Ecology of Neotropical Forest Mammals. Springer.

Nogueira, S.S.C., Fernandes, I.K., Costa, T.S.O., et al., 2015. Does trapping influence decision-making under ambiguity in white-lipped peccary (Tayassu pecari)? PLoS One 10 (6), e0127868.

O'Farrill, G., Galetti, M., Campos-Arceiz, A., 2013. Frugivory and seed dispersal by tapirs: an insight on their ecological role. Integrative Zoology 8, 4-17.

Olson, D.M., Dinerstein, E., 2002. The global 200: priority ecoregions for global conservation. Ann. Mo. Bot. Gard. 89, 125-126.

Olsoy, P.J., Zeller, K.A., Hicke, J.A., et al., 2016. Quantifying the effects of deforestation and fragmentation on a range-wide conservation plan for jaguars. Biol. Conserv. 203, $8-16$.

Peres, C., 1996. Population status of white-lipped Tayassu pecari and collared peccaries $T$. tajacu in hunted and unhunted Amazonian forests. Biol. Conserv. 77, 115-123.

Peres, C.A., Emilio, T., Schietti, J., et al., 2016. Dispersal limitation induces long-term biomass collapse in overhunted Amazonian forests. Proc. Natl. Acad. Sci. 113, 892-897.

Proosdij, A.S.J., Sosef, M.S.M., Wieringa, J.J., Raes, N., 2016. Minimum required number of specimen records to develop accurate species distribution models. Ecography 39, $542-552$.

Rabinowitz, A., Zeller, K.A., 2010. A range-wide model of landscape connectivity and conservation for the jaguar, Panthera onca. Biol. Conserv. 143, 939-945.

Reyna-Hurtado, R., Rojas-Flores, E., Tanner, G.W., 2009. Home range and habitat preferences of white-lipped peccaries (Tayassu pecari) in Calakmul, Campeche, Mexico. J. Mammal. 90, 1199-1209.

Reyna-Hurtado, R., Naranjo, E., Chapman, C., Tanner, G.W., 2010. Hunting and the conservation of a social ungulate: the white-lipped peccary Tayassu pecari in the Calakmul, Mexico. Oryx 44, 88-96.

Reyna-Hurtado, R., Chapman, C.A., Calme, S., Pedersen, E.J., 2012. Searching in het erogenous and limiting environments: foraging strategies of white-lipped peccaries (Tayassu pecari). J. Mammal. 93, 124-133.

Reyna-Hurtado, R., Beck, H., Altrichter, M., Chapman, C.A., et al., 2016. What ecological and anthropogenic factors affect group size in white-lipped peccaries (Tayassu pecari)? Biotropica 48, 246-254. https://doi.org/10.1111/btp.12269.

Reyna-Hurtado, R., Radachowsky, J., Mcloughlin, L., et al., 2017. White-lipped peccary in Mesoamerica: status, threats, and conservation actions. Suiform Soundings 15, $31-35$.
Ripple, W.J., Newsome, T.M., Wolf, C., et al., 2015. Collapse of the world's largest herbivores. Sci. Adv. 1, e1400103.

Ripple, W.J., Abernethy, K., Betts, M.G., et al., 2016. Bushmeat hunting and extinction risk to the world's mammals. R. Soc. Open Sci. 3, 160498.

Robinson, J.G., Redford, K.H., 1986. Intrinsic rate of increase in neotropical forest mammals: relationship to phylogency and diet. Oecologia 68, 516-520.

Rodrigues, A.S.L., Akcakaya, H.R., Andelman, S.J., et al., 2004. Global gap analysis: priority regions for expanding the global protected-area network. Bioscience 54, 1092-1100.

Schank, C.J., Cove, M.V., Kelly, M.J., et al., 2017. Using a novel model approach to assess the distribution and conservation status of the endangered Baird's tapir. Divers. Distrib. 23, 1459-1471.

Searcy, C.A., Schaffer, H.B., 2016. Do ecological niche models accurately identify climatic determinants of species ranges? Am. Nat. 187, 423-435.

Sowls, L.K., 1997. Javelinas and Other Peccaries: Their Biology, Management, and Use, 2nd edition. Texas A\&M University Press.

Steenweg, R., Hebblewhite, M., Kays, R., et al., 2017. Scaling-up camera traps: monitoring the planet's biodiversity with networks of remote sensors. Front. Ecol. Environ. 15, 26-34.

Thornton, D.H., Branch, L.C., 2019. Transboundary mammals in the Americas: asymmetries in protection challenge climate change resilience. Divers. Distrib. 25, 674-683.

Thornton, D.H., Branch, L.C., Sunquist, M.E., 2011. The relative influence of habitat loss and fragmentation: do tropical mammals meet the temperate paradigm? Ecol. Appl. 21, 2324-2333.

Vasilijević, M., Zunckel, K., McKinney, M., et al., 2015. Transboundary conservation: a systematic and integrated approach. In: Best Practice Protected Area Guidelines Series No. 2. IUCN, Gland, Switzerland (p. pp.xii +107).

West, A.M., Kumar, S., Brown, C.S., et al., 2016. Field validation of an invasive species Maxent model. Ecological Informatics 36, 126-134.

Wildlife Conservation Society - WCS, and Center for International Earth Science Information Network - CIESIN - Columbia University, 2005. Last of the Wild Project, Version 2, 2005 (LWP-2): Global Human Footprint Dataset (Geographic). NASA Socioeconomic Data and Applications Center (SEDAC), Palisades, NY. https://doi. org/10.7927/H4M61H5F. (Accessed 12 June 2017).

Wolf, C., Ripple, W.J., 2017. Range contractions of the world's large carnivores. R. Soc Open Sci. 4, 170052.

Wright, S.J., Zeballos, H., Dominguez, I., et al., 2000. Poachers alter mammal abundance, seed dispersal, and seed predation in a neotropical forest. Conserv. Biol. 14, 227-239.

Yackulic, C.B., Sanderson, E.W., Uriarte, M., 2011. Anthropogenic and environmental drivers of modern range loss in large mammals. Proc. Natl. Acad. Sci. 108, 4024-4029. 